\title{
Pola, tren, dan perbedaan praktik menyusui di Indonesia: analisis deskriptif peran modernisasi dan budaya tradisional dari data Survei Demografi Kesehatan Indonesia 2007
}

Siswanto Agus Wilopo ${ }^{1}$

\begin{abstract}
Background: A modernization can lead to the adoption of western behavior while cultural values can also prevails, resulting in rejection of certain aspects of modernity. The question is how such conflicting forces affect breastfeeding practices in Indonesian women.

Objective: This study examined modern and traditional factors that may affect pattern, trends and differentials of breastfeeding in Indonesia.

Method: The study based on data from Indonesian Demographic Health Survey (IDHS) conducted in 2007. There were 32.895 women or 19.939 children born after January 2002 and contributed to this information. We used duration of breastfeeding as dependent variables which based on information pertained to the last two children of respondent. The variable was calculated as the number of months that the mother reports having breastfed the child. The early use of supplementary food for children and the use of health services were examined to represent cultural values and modernity respectively. Socio-economic and demographic variables were considered important variables for breastfeeding practices. Kaplan Meier graphs were employed for the analysis of pattern, trends, and differentials of breastfeeding.

Result: In Indonesia, the duration of breastfeeding varied between provinces. There was a trend of shortening of duration breastfeding about two months during 5 years period. Factors associated with modernity were significant determinant in shortening breastfeeding practice. These included: type of residence (urban or rual), level of education, prenatal care, previous or ever use of contraceptives, delivery at the hospital, and the use of an infant formula.

Conclusion: Factors associated with modernity were significant in terms of early termination of breastfeeding. Traditional factors associated with breastfeeding practice did not show significant roles in maintaining the breastfeeding practice. We recommend to use a social enginering to include breastfeeding practice as a part of modern health practices.
\end{abstract}

KEY WORDS breastfeeding, patterns, trends, differentials, Indonesia

\section{PENDAHULUAN}

Program promosi penggunaan air susu ibu (ASI) melalui upaya kesehatan primer memiliki peran penting dalam meningkatkan kelangsungan hidup bayi dan anak di negara sedang berkembang, termasuk di Indonesia (1-4). Bayi yang memperoleh ASI segera setelah dilahirkan akan memiliki kekebalan tubuh (imunitas) yang lebih tinggi dibanding dengan bayi dan anak yang tidak pernah mendapatkan ASI (5). Dengan demikian bayi yang mendapatkan ASI akan lebih tahan terhadap ancaman penyakit $(2,5)$. Di samping itu, makin lama seorang ibu menyusui bayinya, makin lama pula jarak antarkelahiran bagi anak-anaknya. Hal ini terjadi karena makin lamanya fase tidak subur pascamelahirkan (anovulatory) $(4,6)$ dan melebarnya fase abstinensi (tidak melakukan hubungan seksual) pascapersalinan yang disengaja (2). Lamanya jarak antarkelahiran ( 3 tahun ke atas) telah terbukti memiliki pengaruh positif secara langsung dan tidak langsung terhadap kelangsungan hidup bayi dan anak di negara berkembang (7).

Di Indonesia, pola dan kencenderungan pemberian ASI tidak membaik karena dari tahun ke tahun lama pemberian ASI diduga lebih pendek, atau umur sapih bayi lebih awal (810). Demikian pula praktik menyusui secara eksklusif selama 6 bulan secara terus-menerus mengalami penurunan yang bermakna $(8,9,11)$. Pola dan kencenderungan pemberian ASI sangat mengkhawatirkan bagi penentu kebijakan, terutama jika terjadi pada keluarga miskin dan memiliki status gizi rendah (1). Keluarga tersebut akan memiliki risiko tinggi terhadap kematian bayi dan anaknya (7). Risiko tersebut menjadi lebih tinggi pada keluarga yang tidak melakukan pengaturan kelahiran, sehingga masalah-masalah kesehatan ibu dan anak yang akan dihadapi makin berat $(4,7)$.

Menyusui merupakan tradisi atau praktik turun-temurun yang saat ini mulai terancam akibat modernisasi. Banyak penelitian menunjukkan bahwa melemahnya tradisi dalam pemberian ASI merupakan akibat terjadinya proses modernisasi $(2,11,12)$. Secara umum, dapat dipahami bahwa modernisasi mendorong perilaku seseorang untuk meninggalkan praktik tradisional (12). Menyusui dianggap sebagai salah satu bentuk perilaku tradisional yang tidak menjadi ciri-ciri kehidupan modern seorang ibu pada masa sekarang. Hal inilah yang menyebabkan ibu-ibu pada masa sekarang mendambakan praktik-praktik modern selain

Magister Kesehatan Ibu dan Anak-Kesehatan Reproduksi (KIA-KR) UGM, Jl. Farmako, Sekip Utara 55281, e-mail: sawilopo@yahoo.com 
memberikan ASI dalam perawatan kesehatan anak. Salah satu bentuk pemahaman gizi dan kesehatan modern yang salah yaitu praktik pemberian minuman dan makanan dalam bentuk formula baru (buatan pabrik) (12). Hal ini dilakukan seiring dengan ditinggalkannya praktik perawatan tradisional secara perlahan-lahan, seperti pemberian air tajin (air dari rebusan beras), madu, dan makanan padat tradisional lainnya (13). Praktik-praktik modern tersebut umumnya bertentangan dengan konsep pemberian ASI secara eksklusif (14). Hal ini dapat berakibat pada lama menyusui yang lebih singkat melalui mekanisme fisiologis yang sangat kompleks $(2,11)$.

Bekerja di luar rumah seringkali dianggap sebagai salah satu ciri-ciri wanita modern (14). Wanita yang hanya berperan sebagai ibu rumah tangga dan bekerja di rumah saja seringkali dianggap sebagai wanita tradisional. Berdasarkan teori, bekerja di luar rumah bagi seorang ibu dapat mengurangi waktu dan frekuensi pemberian ASI kepada bayinya $(12,14)$. Dengan demikian, praktik-praktik modern tersebut dapat melawan pengaruh tradisi yang masih melekat di masyarakat, sehingga perubahan perilaku menyusui secara perlahan-lahan akan mengikuti perkembangan proses modernisasi. Oleh karena itu, pola dan tren lamanya pemberian ASI akan bervariasi menurut kecepatan dan tingkat modernisasi yang diadopsi oleh ibu-ibu di masyarakat (12).

Pengaruh modernisasi dan praktik-praktik tradisional terjadi secara simultan di masyarakat. Pengaruh tersebut secara umum merupakan dampak dari pengaruh modernisasi dan tradisi yang masih tetap dipertahankan (12). Proses modernisasi tersebut membutuhkan waktu yang cukup lama, sehingga pengaruhnya mungkin belum dirasakan secara nyata pada saat ini. Pengaruh tarik-menarik antara adopsi budaya modern dan tradisional dalam pemberian ASI belum pernah diteliti secara nasional menggunakan data yang cukup mewakili Indonesia. Penelitian ini bertujuan untuk menjelaskan pola, tren, dan perbedaan praktik menyusui bayi dan anak di berbagai provinsi di Indonesia menggunakan data Survei Demografi Kesehatan Indonesia (SDKI) tahun 2007.

\section{BAHAN DAN METODE}

\section{Sumber data}

Penelitian ini menggunakan data SDKI tahun 2007 (8). Cara pemilihan sampel dan metode sampling serta proses pengumpulan data dan hasil analisis data secara sederhana terdapat pada laporan lengkap dari survei-survei tersebut dan informasi yang dikumpulkan mencakup berbagai aspek, antara lain: latar belakang keluarga, keinginan dan perilaku reproduksi, ketersediaan alat dan pelayanan kontrasepsi, pola menyusui dan pemberian makan bayi, serta kematian ibu, bayi, dan anak. Penelitian ini berbeda dengan laporan resmi hasil SDKI tahun 2007 yang menggunakan data anakanak bungsu yang lahir 3 tahun sebelum survei. Penelitian ini mencakup informasi tentang sejarah kehamilan serta kelahiran dan kematian bayi dan anak yang dikumpulkan dari peristiwa yang terjadi 5 tahun sebelum survei. Informasi tentang menyusui dikumpulkan dari 2 anak terakhir yang dilahirkan, baik anak-anak tersebut masih hidup atau sudah meninggal.

Besar sampel penelitian untuk SDKI tahun 2007 yaitu 40.701 rumah tangga, yang terdiri dari 32.895 wanita usia subur (15-49 tahun). Di antara wanita tersebut, kelahiran dua anak terakhir, baik yang masih hidup maupun yang sudah meninggal berjumlah 19.939 anak. Beberapa di antara bayi tersebut pada saat dilakukan kunjungan survei masih dalam keadaan menyusui, sehingga belum diketahui dengan pasti waktu bayi akan disapih (observasi censored). Observasi censored merupakan observasi yang berkaitan dengan waktu terjadinya hasil akhir penelitian (lama menyapih) yang belum dapat diamati kejadiannya, karena sampai dengan akhir penelitian anak tersebut belum disapih. Dalam hal ini, waktu lamanya menyusui paling sedikit sama dengan umur bayi tersebut, tetapi waktu bayi akan disapih belum diketahui. Fakta yang ada yaitu pada saat dilakukan kunjungan rumah (sama dengan umur anak pada saat kunjungan), anak-anak tersebut belum disapih atau masih menyusui. Jadi waktu bayi disapih akan lebih lama daripada umur bayi pada saat dilakukan observasi.

Bayi yang meninggal (sejumlah 694 anak) juga diberi pertanyaan mengenai kondisi anak tersebut saat meninggal, yaitu masih menyusui atau sudah disapih. Bayi yang telah meninggal maupun yang masih hidup tersebut memberi kontribusi informasi pada penelitian ini.

Data pokok untuk penelitian ini bersumber dari pertanyaan penelitian dengan kode blok 4 (kehamilan, perawatan pascamelahirkan, dan menyusui). Informasi lainnya, khususnya tingkat sosial ekonomi yang diolah dari hasil pertanyaan blok rumah tangga menggunakan cara perhitungan indeks kekayaan (wealth index) yang biasa digunakan oleh lembaga-lembaga donor internasional (15).

\section{Variabel penelitian}

Variabel tergantung (dependen) dalam penelitian ini adalah lamanya menyusui seorang balita dari dua anak yang terakhir dilahirkan oleh sampel wanita berusia 15-49 tahun. Variabel ini dihitung dari lamanya menyusui dalam bulan atas dasar informasi yang ditanyakan kepada ibunya. Variabel lama menyusui yang akan diolah maksimal 48 bulan. Karena data ini dikumpulkan dari hasil survei, beberapa anak-anak tidak dapat diketahui waktu penyapihan, kecuali jika diketahui status lama menyusui minimal yang sesuai dengan umur anak tersebut (censored). Dalam penyajian data secara deskriptif, observasi censored tidak dianalisis, sedangkan pada analisis survival, informasi tersebut akan dimasukkan. Cara ini dilakukan untuk menghindari pengaruh observasi lama menyusui yang nilainya ekstrim (baru beberapa hari lahir) pada saat digunakan analisis sederhana dengan cara tabulasi sederhana. Perlu dicatat bahwa nilai ekstrim akan sangat 
besar pengaruhnya terhadap nilai rata-rata lama menyusui yang akan disajikan secara deskriptif pada penelitian.

Variabel bebas (independen) dalam penelitian ini mencakup 3 kelompok konsep variabel, yaitu: pertama, variabel yang menggambarkan pola pemberian ASI, minuman dan makanan tambahan yang diberikan. Variabel ini terdiri dari: waktu pemberian ASI untuk pertama kali serta jenis minuman dan makanan tambahan selain ASI. Dari pengukuran ini dapat dibedakan konsep antara bahan yang mengandung bahanbahan tradisional dan modern. Jenis kelamin bayi atau anak akan diperhitungkan untuk melihat praktik menyusui terkait dengan jenis kelamin anak atau tidak. Kedua, konsep variabel pelayanan kesehatan modern dan tradisional diukur dari variabel pemeriksa kesehatan bayi pascamelahirkan, tempat melahirkan, dan riwayat penggunaan kontrasepsi sebelumnya. Ketiga, variabel latar belakang demografi dan sosial ekonomi yang terdiri dari tingkat pendidikan, jenis pekerjaan orang tua, tingkat status ekonomi (wealth index), tipe tempat tinggal (desa atau kota), dan provinsi tempat tinggal responden akan dianalisis untuk menggambarkan peran modernisasi.

Dengan demikian, masing-masing kelompok variabel dapat dikaitkan dengan konsep dan indikator praktik-praktik modern dan tradisional. Di samping itu, untuk melihat tren menyusui akan dibandingkan kurva kelangsungan menyusui antara data SDKI tahun 2007 dengan data serupa (SDKI) tahun 2002-2003 (9).

\section{Analisis data deskriptif dan statistik semiparametrik}

Data rata-rata, standar deviasi, dan median lama menyusui disajikan secara deskriptif untuk masing-masing karakteristik ketiga kelompok jenis variabel bebas tersebut. Mengingat lama menyusui mencakup informasi yang bersifat censored, maka pada analisis deskriptif dengan cara ini tidak akan dimasukkan observasi censored. Analisis yang mengikutsertakan data censored akan dilakukan menggunakan kurva dari Kaplan dan Meier dan uji statistik log-rank (statistik semiprametrik) serta menggunakan program komputer STATA versi 9 (16). Hasil analisis deskriptif ini akan dijadikan dasar untuk melakukan analisis multivariabel pada publikasi yang akan datang.

\section{HASIL}

\section{Karakteristik sampel penelitian}

Di antara 32.895 wanita usia subur dalam sampel SDKI tahun 2007, tercatat sejumlah 1.939 anak yang lahir terakhir (bungsu) dan kedua dari terakhir (kakak anak bungsu) dengan lama menyusui kurang dari 48 bulan (8). Dengan menggunakan analisis deskriptif menggunakan informasi anak-anak yang benar-benar telah disapih, terdapat 13.121 anak yang diketahui lama menyusuinya. Anak-anak inilah yang dianalisis dan disajikan hasilnya pada Tabel 1 dan Tabel 2 berikut.

\section{Pola menyusui tiap provinsi dan modernisasi serta budaya tradisional}

Tabel 1 menyajikan pola menyusui menurut umur sapih dalam angka-angka median, angka rata-rata, standar deviasi, serta jumlah bayi yang telah disapih pada 33 provinsi di Indonesia. Data ini hanya memasukkan data bayi yang sudah disapih, tetapi tidak melihat data status kehidupan bayi (masih hidup atau sudah meninggal). Berdasarkan tabel tersebut tampak bahwa median lama menyusui secara nasional adalah 17 bulan. Median lama menyusui di 28 provinsi berkisar antara 12 sampai dengan 18 bulan dan 4 provinsi memiliki median lama menyusui 18 bulan ke atas. Wanita dari Jawa Tengah dan Daerah Istimewa Yogyakarta memiliki angka median dan rata-rata menyusui paling panjang (21 bulan), sedangkan wanita dari Kepulauan Riau memiliki waktu lama menyusui paling singkat ( 6 bulan). Namun demikian, perlu dicatat bahwa angka 6 bulan ini masih memerlukan kajian lebih lanjut yang menyangkut kualitas data yang dikumpulkan. Di DKI Jakarta yang relatif lebih maju, terdapat banyak wanita yang bekerja di luar rumah dan ternyata memiliki angka menyusui yang terendah sesudah Kepulauan Riau (12 bulan). Provinsi dengan budaya kultural yang masih relatif kuat (termasuk Jawa Tengah dan Daerah Istimewa Yogyakarta) memiliki pola menyusui yang lebih lama dibandingkan dengan provinsi-provinsi lainnya. Dari perbedaan pola antara provinsi tersebut, dapat dikaji lebih lanjut faktor-faktor yang lebih berperan dalam menentukan pola menyusui pada masing-masing provinsi.

Perbedaan tersebut kemungkinan terkait dengan karakteristik 3 faktor utama berikut, yaitu: praktik budaya (tradisi) pemberian ASI atau makanan bayi, adopsi terhadap budaya modern dalam bentuk penggunaan pelayanan kesehatan, dan pengaruh latar belakang sosial-ekonomi keluarga. Sebagai contoh adalah pemberian ASI atau makanan tambahan berupa susu formula berhubungan dengan probabilitas lama menyusui yang lebih singkat dibanding dengan pemberian makanan tambahan secara tradisional atau tanpa pemberian makanan tambahan (Tabel 2). Sebagian besar wanita memberikan makanan pendamping ASI (PASI) pada anak yang baru berusia 3 hari dan hanya 37 persen yang tidak memberikan apapun pada hari ketiga setelah dilahirkan. Selain itu, analisis secara kasar yang belum disajikan dalam tabel ini juga memberikan indikasi kuat bahwa menyusui secara eksklusif (exclusive breastfeeding) tampaknya sangat rendah, karena sebagian besar bayi sebelum usia 6 bulan sudah mendapatkan PASI. Dengan demikian dapat disimpulkan secara awal bahwa pengaruh penggunaan minuman formula modem berhubungan dengan probabilitas umur penyapihan anak yang lebih awal. Perlu dicatat bahwa anak laki-laki memiliki median umur disapih lebih rendah 2 bulan dibanding perempuan (median 16 vs 18 bulan).

Penerimaan budaya kesehatan modern ditandai dengan perilaku untuk mengadopsi perawatan pascamelahirkan dan penggunaan kontrasepsi sebagai alat pengatur kelahiran. Hasil 
TABEL 1. Pola menyusui menurut umur sapih tiap provinsi di Indonesia

\begin{tabular}{|c|c|c|c|c|c|}
\hline \multirow[b]{2}{*}{ Provinsi } & \multicolumn{3}{|c|}{ Angka statistik } & \multirow[b]{2}{*}{ Jumlah } & \multirow[b]{2}{*}{$\%$} \\
\hline & Median & Rata-rata & $\begin{array}{l}\text { Standar } \\
\text { deviasi }\end{array}$ & & \\
\hline D.I. Aceh & 18 & 16,7 & 7,82 & 417 & 3,1 \\
\hline Sumatra Utara & 12 & 13,1 & 8,17 & 653 & 4,9 \\
\hline Sumatra Barat & 18 & 17,3 & 8,14 & 457 & 3,4 \\
\hline Riau & 18 & 14,8 & 9,71 & 429 & 3,2 \\
\hline Jambi & 20 & 17,9 & 9,08 & 297 & 2,2 \\
\hline Sumatra Selatan & 18 & 17,1 & 9,10 & 384 & 2,9 \\
\hline Bengkulu & 18 & 17,9 & 7,66 & 290 & 2,2 \\
\hline Lampung & 18 & 16,6 & 8,82 & 305 & 2,3 \\
\hline Bangka Belitung & 17 & 13,5 & 9,95 & 329 & 2,5 \\
\hline Kepulauan Riau & 6 & 9,5 & 9,80 & 408 & 3,1 \\
\hline D.K.I. Jakarta & 12 & 12,6 & 9,64 & 678 & 5,1 \\
\hline Jawa Barat & 19 & 16,8 & 9,70 & 565 & 4,3 \\
\hline Jawa Tengah & 21 & 17,9 & 9,95 & 387 & 2,9 \\
\hline D.I. Yogyakarta & 21 & 17,2 & 9,63 & 311 & 2,3 \\
\hline Jawa Timur & 17 & 14,9 & 10,13 & 395 & 3,0 \\
\hline Banten & 18 & 15,8 & 9,34 & 528 & 4,0 \\
\hline Bali & 18 & 15,2 & 9,08 & 394 & 3,0 \\
\hline Nusa Tenggara Barat & 18 & 17,8 & 7,88 & 402 & 3,0 \\
\hline Nusa Tenggara Timur & 14 & 15,4 & 7,86 & 449 & 3,4 \\
\hline Kalimantan Barat & 15 & 15,6 & 11,14 & 315 & 2,4 \\
\hline Kalimantan Tengah & 20 & 17,2 & 9,47 & 299 & 2,2 \\
\hline Kalimantan Selatan & 18 & 16,0 & 10,43 & 345 & 2,6 \\
\hline Kalimantan Timur & 15 & 14,9 & 10,55 & 332 & 2,5 \\
\hline Sulawesi Utara & 12 & 12,5 & 8,36 & 345 & 2,6 \\
\hline Sulawesi Tengah & 18 & 16,0 & 9,33 & 390 & 2,9 \\
\hline Sulawesi Selatan & 14 & 15,4 & 9,03 & 498 & 3,7 \\
\hline Sulawesi Tenggara & 15 & 14,9 & 8,93 & 394 & 3,0 \\
\hline Gorontalo & 12 & 13,7 & 9,07 & 298 & 2,2 \\
\hline Sulawesi Barat & 16 & 15,5 & 9,57 & 380 & 2,8 \\
\hline Maluku & 12 & 11,9 & 7,22 & 470 & 3,5 \\
\hline Maluku Utara & 12 & 13,1 & 8,76 & 376 & 2,8 \\
\hline Papua & 12 & 11,9 & 7,84 & 331 & 2,5 \\
\hline Papua Barat & 18 & 16,4 & 10,25 & 270 & 2,0 \\
\hline Total & 17 & 15,1 & 9,35 & 13121 & 100 \\
\hline
\end{tabular}

Keterangan:

Pola menyusui dan umur sapih dinyatakan dalam satuan bulan.

Data bersumber dari Survei Demografi Kesehatan Indonesia (SDKI) tahun 2007.

analisis lama menyusui menurut perbedaan perilaku tersebut mendukung hipotesis bahwa perilaku kesehatan modern justru terjadi pada wanita yang lama menyusuinya lebih singkat. Wanita yang melakukan perawatan pascamelahirkan atau melahirkan di rumah sakit cenderung menyusui lebih singkat dibanding kelompok lainnya. Wanita dengan riwayat pernah menggunakan kontrasepsi memiliki waktu menyusui yang lebih singkat dibanding bukan pengguna kontrasepsi (Tabel 2).

Latar belakang sosial ekonomi keluarga dengan modernisasi sangat erat kaitannya dengan pola menyusui. Wanita yang tergolong ke dalam tingkatan sosial-ekonomi rendah, bekerja di sektor pertanian, atau hanya bekerja sebagai ibu rumah-tangga memiliki kebiasaan menyusui yang lebih panjang dibanding dengan wanita yang bekerja pada sektor informal, pegawai negeri, atau sebagai pedagang (perkantoran). Demikian juga hubungan jenis pekerjaan suami dengan lama menyusui istrinya tidak jauh berbeda dengan pekerjaan wanita. Lama menyusui pada wanita dengan pendidikan tinggi cenderung lebih singkat dibanding dengan wanita yang berpendidikan rendah. Tabel 2 menunjukkan lama menyusui bagi wanita dari daerah perkotaan lebih singkat dibandingkan dengan wanita dari perdesaan. Perkotaan pada dasarnya merupakan ciri dari hasil modernisasi di berbagai bidang.

\section{Tren lama menyusui}

Untuk dapat memanfaatkan informasi lama menyusui dari pengamatan censored, digunakan analisis survival (kelangsungan hidup) secara nonparametrik. Pada Gambar 1 disajikan tren penurunan lama menyusui yang diolah dari data SDKI tahun 2007 dan dibandingkan dengan data SDKI tahun 2002-2003. Dengan mengikutsertakan informasi censored dan lama menyusui kurang dari 48 bulan, jumlah anak yang dapat dianalisis untuk SDKI tahun 2007 adalah 1.939 anak. Sebagai pembanding tren penurunan lama menyusui, data menyusui diambil dari hasil SDKI tahun 2002-2003 yang mencakup informasi sebanyak 18.310 anak. Melalui grafik tersebut, tampak bahwa probabilitas lama menyusui untuk 
TABEL 2. Lama menyusui wanita Indonesia menurut karakteristik praktik pemberian ASI/PASI, penggunaan pelayanan kesehatan, dan sosial ekonomi keluarga

\begin{tabular}{|c|c|c|c|c|c|}
\hline \multirow[b]{2}{*}{ Karakteristik } & \multicolumn{3}{|c|}{ Angka statistik } & \multirow[b]{2}{*}{ Jumlah } & \multirow[b]{2}{*}{$\%$} \\
\hline & Median & Rata-rata & $\begin{array}{l}\text { Standar } \\
\text { deviasi }\end{array}$ & & \\
\hline \multicolumn{6}{|l|}{ Jenis kelamin anak } \\
\hline Laki-laki & 16 & 14,9 & 9,39 & 6892 & 52,5 \\
\hline Perempuan & 18 & 15,4 & 9,31 & 6229 & 47,4 \\
\hline \multicolumn{6}{|l|}{ Pemberian pengganti ASI } \\
\hline Tanpa PASI & 18 & 17,4 & 8,07 & 4490 & 37,4 \\
\hline Madu dan air & 18 & 17,1 & 7,87 & 3059 & 25,4 \\
\hline Makanan semipadat & 18 & 17,9 & 8,14 & 308 & 2,5 \\
\hline Susu formula & 17 & 15,0 & 9,23 & 4140 & 34,5 \\
\hline \multicolumn{6}{|l|}{$\begin{array}{l}\text { Pemberian PASI } 3 \text { hari setelah } \\
\text { kelahiran }\end{array}$} \\
\hline Tidak & 18 & 17,4 & 8,07 & 4490 & 37,4 \\
\hline $\mathrm{Ya}$ & 18 & 16,0 & 8,72 & 7507 & 62,5 \\
\hline \multicolumn{6}{|l|}{ Tempat melahirkan } \\
\hline Rumah & 18 & 16,2 & 8,83 & 7609 & 58,1 \\
\hline Klinik dan lainnya & 14 & 13,8 & 9,96 & 3950 & 30,1 \\
\hline Rumah sakit & 12 & 13,4 & 9,60 & 1541 & 11,7 \\
\hline \multicolumn{6}{|l|}{ Perawatan postnatal } \\
\hline Tidak atau dukun & 16 & 15,6 & 8,93 & 4081 & 31,3 \\
\hline Bidan & 18 & 15,6 & 9,29 & 7298 & 55,9 \\
\hline Dokter & 10 & 11,8 & 9,99 & 1658 & 12,7 \\
\hline \multicolumn{6}{|l|}{ Riwayat pemakaian kontrasepsi } \\
\hline $\mathrm{Ya}$ & 18 & 15,4 & 9,37 & 11510 & 87,7 \\
\hline Tidak & 12 & 13,3 & 9,08 & 1611 & 12,2 \\
\hline \multicolumn{6}{|l|}{ Paritas } \\
\hline 1 & 15 & 13,9 & 9,72 & 3058 & 23,3 \\
\hline 2 & 18 & 15,3 & 9,29 & 3992 & 30,4 \\
\hline 3 & 17 & 15,4 & 9,22 & 2676 & 20,4 \\
\hline $4+$ & 17 & 15,8 & 9,12 & 3395 & 25,8 \\
\hline \multicolumn{6}{|l|}{ Pekerjaan ibu } \\
\hline Tidak bekerja & 15 & 14,5 & 9,37 & 6158 & 58,3 \\
\hline Petani & 18 & 17,4 & 8,57 & 2872 & 27,2 \\
\hline Informal dan pegawai negeri & 13 & 13,7 & 9,57 & 1524 & 14,4 \\
\hline \multicolumn{6}{|l|}{ Pendidikan ibu } \\
\hline Tidak sekolah atau SD & 18 & 16,1 & 9,09 & 5499 & 41,9 \\
\hline SMP atau SMA & 16 & 14,7 & 9,42 & 6506 & 49,5 \\
\hline Universitas & 12 & 12,7 & 9,65 & 1116 & 8,5 \\
\hline \multicolumn{6}{|l|}{ Pekerjaan ayah } \\
\hline Tidak bekerja & 12 & 12,6 & 8,87 & 334 & 3,5 \\
\hline Petani & 18 & 16,4 & 8,84 & 4764 & 50,3 \\
\hline Informal dan pegawai negeri & 15 & 14,5 & 9,55 & 4374 & 46,1 \\
\hline \multicolumn{6}{|l|}{ Indeks kekayaan } \\
\hline Rendah & 17 & 16,0 & 8,78 & 3727 & 28,4 \\
\hline Sedang & 18 & 15,4 & 9,39 & 7080 & 53,9 \\
\hline Tinggi & 12 & 12,9 & 9,78 & 2314 & 17,6 \\
\hline \multicolumn{6}{|l|}{ Tempat tinggal } \\
\hline Desa & 18 & 16,1 & 8,92 & 7799 & 59,4 \\
\hline Kota & 13 & 13,7 & 9,79 & 5322 & 40,5 \\
\hline Indonesia & 17 & 15,1 & 9,35 & 13121 & 100 \\
\hline
\end{tabular}

Keterangan:

Lama menyusui dinyatakan dalam satuan bulan.

Sampel cukup besar, sehingga uji perbedaan mean selalu menghasilkan signifikansi secara statistik.

Data bersumber dari Survei Demografi Kesehatan Indonesia (SDKI) tahun 2007.

semua periode lama menyusui (dari 0 sampai dengan 48 bulan) hasil SDKI tahun 2007 selalu lebih rendah dibandingkan dengan SDKI tahun 2002-2003. Hal ini menunjukkan adanya kecenderungan penurunan lama menyusui yang konsisten untuk semua pola lama menyusui. Median survival time untuk kedua periode pengumpulan data SDKI tersebut adalah 16 dan 14 bulan. Dengan uji log-rank, perbedaan tersebut secara statistik bermakna. Dengan kata lain, dalam rentang waktu 5 tahun (antara SDKI tahun 2002-2003 sampai dengan 2007), setengah dari wanita Indonesia mengalami tren penurunan lama menyusui sekitar 2 bulan. Secara statistik, penurunan tersebut berbeda secara bermakna $(p<0,05)$. 


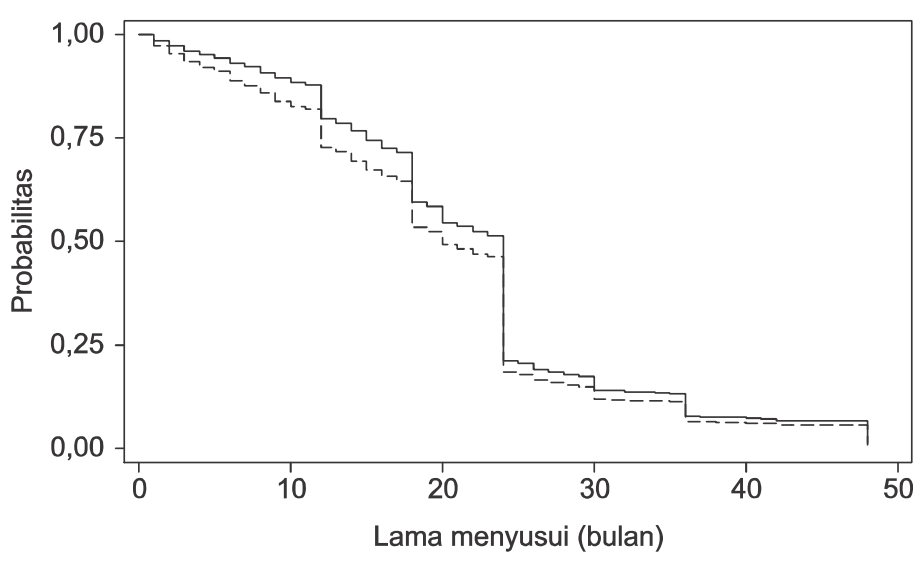

SDKI 2002-2003 ----- SDKI 2007

\section{GAMBAR 1. Tren kurva Kaplan-Meier kelangsungan menyusui di Indonesia menurut data SDKI} tahun 2002-2003 dan 2007

\section{Berbagai faktor penyebab timbulnya perbedaan lama menyusui}

Pemaparan secara grafik menggunakan cara Kaplan Meier dan uji statistik log-rank digunakan untuk melihat perbedaan pengaruh budaya pemberian makanan bayi, adopsi intervensi kesehatan modern, pendidikan wanita, pekerjaan dan tingkat sosial-ekonomi keluarga (indeks kekayaan), dan tempat tinggal (urban dan rural). Berbagai variabel tersebut dapat merepresentasikan pengaruh tingkat modernisasi dan perilaku kultural yang terkait dengan lama pemberian ASI. Pada Gambar 2 diketahui bayi yang memperoleh makanan tambahan terdiri dari susu formula atau makanan formula (minuman-makanan modern) memiliki waktu sapih lebih singkat dibanding kelompok lainnya. Bayi yang setelah lahir tidak diberikan makanan dan minuman selama 3 hari pertama dan/atau menerima makanan setengah padat (dapat dikaitkan dengan budaya tradisional), probabilitas umur sapihnya lebih tua.

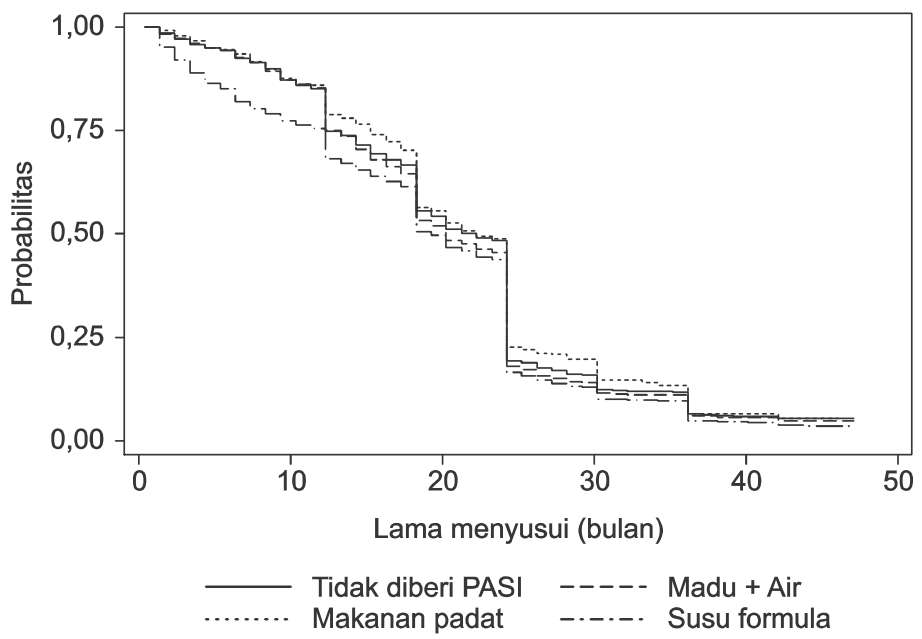

GAMBAR 2. Kurva Kaplan-Meier kelangsungan menyusui di Indonesia menurut pemberian PASI dari data SDKI tahun 2007
Pada Gambar 3 diketahui wanita yang memperoleh perawatan pascamelahirkan (postnatal care) oleh dokter umum atau dokter spesialis memiliki probabilitas menyusui lebih singkat dibanding wanita yang dirawat oleh bidan, demikian pula wanita yang dirawat oleh dukun serta yang tidak mendapatkan perawatan pascamelahirkan akan lebih tinggi probabilitasnya untuk menyusui lebih lama. Perawatan oleh dokter umum atau dokter spesialis digunakan sebagai indikator terhadap perilaku wanita yang telah mengadopsi teknologi kedokteran modern. Hubungan tersebut sangat bermakna pada bayi (usia $<12$ bulan) dan mulai berkurang setelah anak berusia 2 tahun. Penemuan ini menunjukkan bahwa perawatan pascamelahirkan oleh dokter umum atau dokter spesialis tidak berpengaruh positif terhadap perilaku ibu untuk menyusui bayinya, tetapi justru berpengaruh negatif.

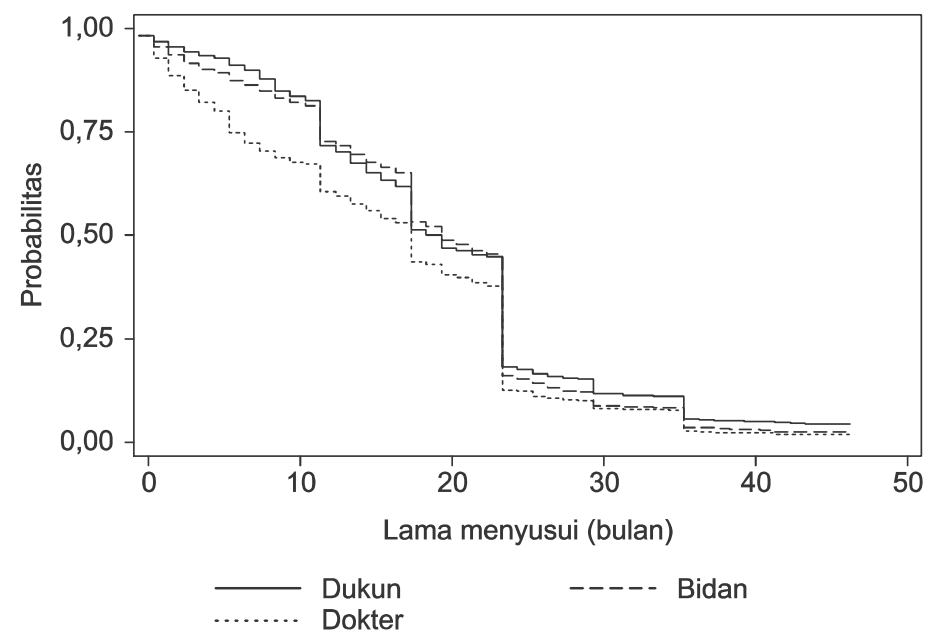

GAMBAR 3. Kurva Kaplan-Meier kelangsungan menyusui di Indonesia menurut tempat perawatan pascamelahirkan dari data SDKI tahun 2007

Riwayat penggunaan kontrasepsi sebelum melahirkan bayi yang menjadi sampel penelitian ini sebagai indikator terhadap modernisasi dari kehidupan keluarga yang telah mempraktikkan upaya pengaturan reproduksi. Keluarga yang belum mengenal konsep pengaturan kelahiran, umumnya terdiri dari golongan tradisional. Pada Gambar 4 tampak bahwa hubungan riwayat penggunaan kontrasepsi dengan probabilitas memendeknya lama menyusui hanya jelas saat anak berusia antara 12-30 bulan. Hubungan tersebut paling jelas terjadi pada saat anakanak berusia 12-24 bulan. Pada tahun pertama, tidak terdapat perbedaan pola menyusui wanita yang pernah memakai kontrasepsi dan belum pernah memakai alat kontrasepsi.

Tingkat pendidikan wanita menjadi indikator terhadap perilaku modernisasi yang diadopsi oleh keluarga. Wanita berpendidikan lebih tinggi cenderung memiliki probabilitas untuk menyusui lebih singkat dibandingkan dengan wanita yang tidak berpendidikan atau pendidikan yang lebih rendah. Pada Gambar 5 diketahui hubungan tersebut sangat jelas, yaitu wanita berpendidikan tinggi cenderung melakukan 


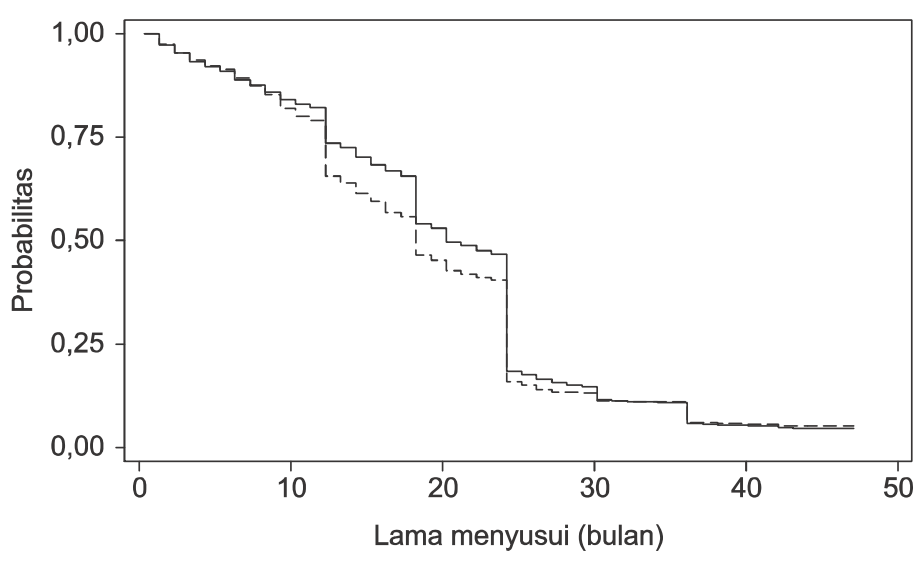

_ Pernah pakai _ - ---- Belum pernah pakai

GAMBAR 4. Kurva Kaplan-Meier kelangsungan menyusui di Indonesia menurut riwayat penggunaan kontrasepsi dari data SDKI tahun 2007

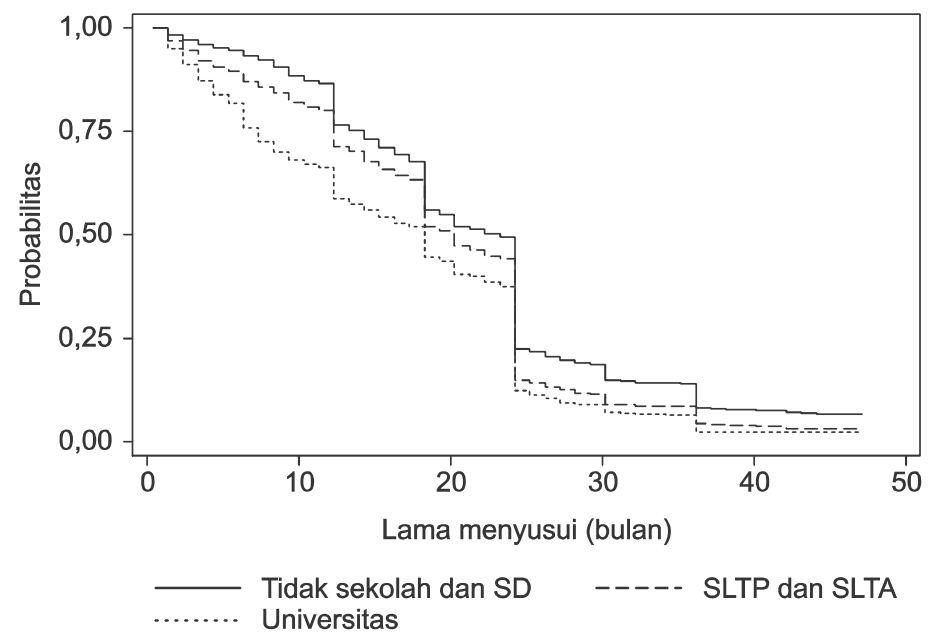

GAMBAR 5. Kurva Kaplan-Meier kelangsungan menyusui di Indonesia menurut tingkat pendidikan wanita dari data SDKI tahun 2007

penyapihan lebih awal dibanding dengan kedua kelompok lainnya. Secara logika, wanita yang berpendidikan lebih tinggi seharusnya lebih memahami arti pentingnya ASI bagi kesehatan anak. Berdasarkan data tersebut terbukti perilaku menyapih bagi yang berpendidikan perguruan tinggi justru relatif lebih awal dibanding dengan kelompok lainnya.

Kemiskinan dalam penelitian ini diukur dari indeks kekayaan (5 kategori), kemudian disederhanakan menjadi 3 kategori, yaitu: miskin (di bawah 25 persentil), cukup (antara 25-75 persentil), dan kaya (di atas 75 persentil). Kemiskinan merupakan salah satu akibat dari tertinggalnya keluarga dalam proses modernisasi pembangunan. Namun demikian, pada Gambar 6 justru tampak bahwa makin miskin suatu keluarga, makin baik perilaku dalam menyusui. Hal ini ditandai dengan makin tingginya probabilitas menyusui untuk tiap umur. Dengan demikian, wanita yang termasuk dalam kelompok kaya memiliki probabilitas untuk menyapih lebih awal dibanding yang miskin. Wanita yang miskin lebih banyak

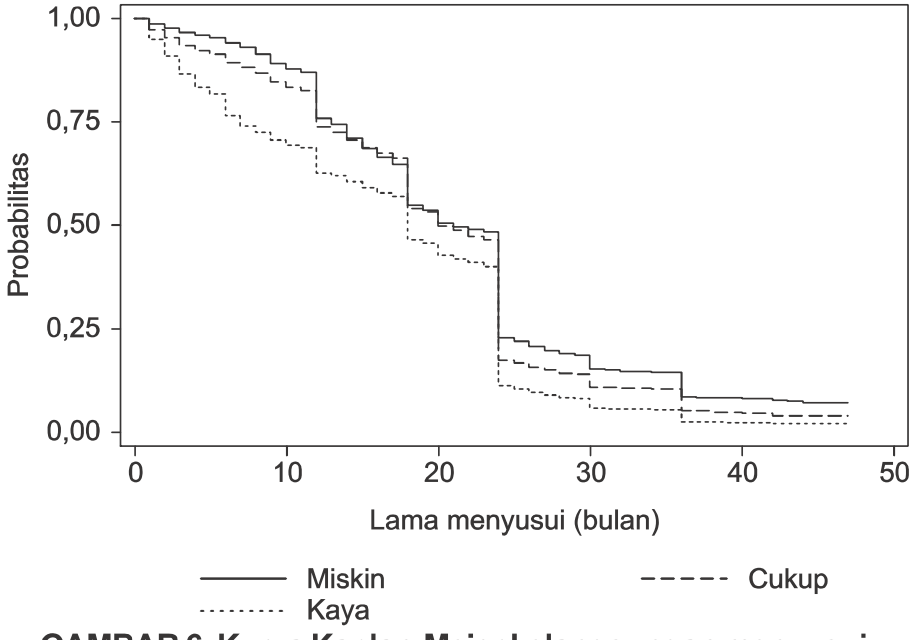

GAMBAR 6. Kurva Kaplan-Meier kelangsungan menyusui di Indonesia menurut indeks kekayaan keluarga (wealth index) dari data SDKI tahun 2007

yang bertempat tinggal di daerah pedesaan. Daerah pedesaan bukan hanya menjadi kantong-kantong kemiskinan, tetapi daerah tersebut juga dapat dikatakan tertinggal dalam proses modernisasi dibanding daerah perkotaan. Pada Gambar 7 tampak bahwa probabilitas lama menyusui pada wanita yang bertempat tinggal di pedesaan lebih lama dibanding dengan wanita yang tinggal di daerah perkotaan. Hasil-hasil tersebut di atas dapat membuktikan bahwa modernisasi tidak secara langsung memperbaiki pola menyusui ibu, justru sebaliknya modernisasi dapat dihubungkan dengan makin terkikis habisnya budaya tradisional dalam menyusui bayi.

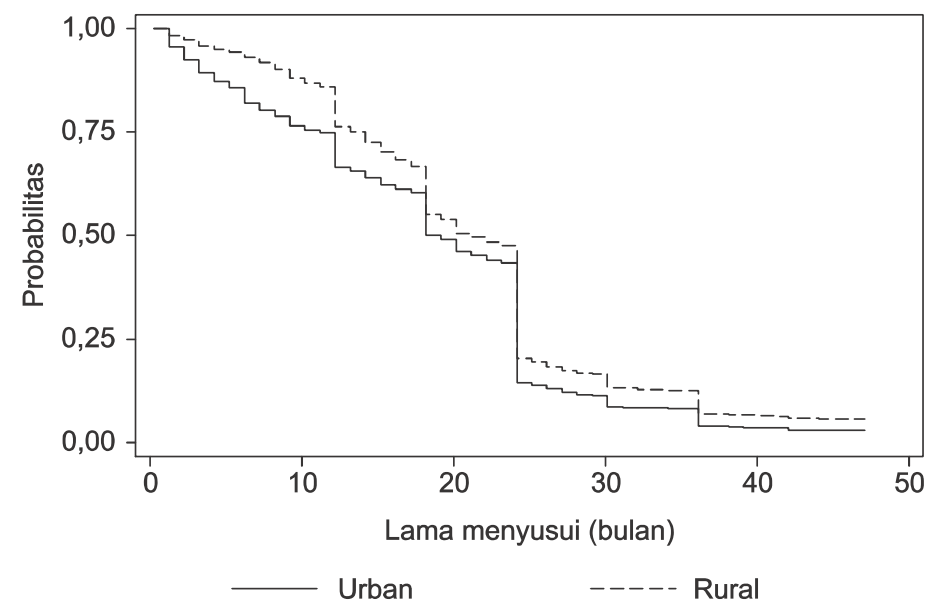

GAMBAR 7. Kurva Kaplan-Meier kelangsungan menyusui di Indonesia menurut tempat tinggal (urban atau rural) dari data SDKI tahun 2007

\section{BAHASAN}

Penelitian ini mengungkap pola menyusui yang bervariasi antarprovinsi di Indonesia. Berbeda dengan buku laporan lengkap hasil SDKI tahun 2007 yang telah dipublikasi, penelitian ini tidak hanya menggunakan sampel anak-anak bungsu yang 
lahir dalam periode tiga tahun sebelum survei (8). Penelitian ini menggunakan semua data anak-anak yang lahir sejak bulan Januari tahun 2002 dan merupakan anak-anak bungsu atau anak-anak nomor dua dari terakhir (kakak bungsu). Di samping itu, lama menyusui diasumsikan tidak lebih dari 4 tahun (48 bulan). Dari sampel yang berbeda ini, dapat dimaklumi apabila hasil penelitian ini memiliki median lama menyusui relatif lebih singkat dibanding laporan resmi hasil SDKI tahun 2007.

Perbedaan hasil tersebut dapat dijelaskan dari perbedaan distribusi sampel menurut paritas ibu. Dengan memasukkan data penyapihan anak kedua dari paling akhir dapat memberi peluang lebih besar untuk mengikutsertakan data penyapihan dari ibu dengan paritas tinggi. Sebagai konsekuensinya, analisis data anak umur 3 tahun ke bawah (laporan SDKI tahun 2007) mencakup lebih banyak ibu dengan paritas rendah dibanding analisis data yang mencakup anak-anak yang lahir 5 tahun sebelum survei. Pada data SDKI tahun 2007 diketahui sampel yang hanya dibatasi pada anak-anak usia kurang dari 3 tahun, sehingga ditemukan wanita dengan paritas 1 anak sebanyak 29 persen; sedangkan untuk sampel dengan anak-anak yang lahir 5 tahun sebelum survei maka sampel dari wanita dengan paritas 1 sebesar 25 persen. Angka serupa untuk paritas ke-4 atau lebih adalah 23 persen dan 25 persen. Dengan demikian, data menyusui dari ibu-ibu dengan paritas 1 lebih sedikit dibanding dengan laporan resmi SDKI tahun 2007. Oleh karena itu, dapat dipahami dengan mudah alasan median lama menyusui secara nasional lebih singkat (17 bulan) dibandingkan dengan laporan SDKI tahun 2007 (20 bulan). Hal ini disebabkan ibu-ibu yang memiliki anak lebih banyak (paritas tinggi) cenderung memiliki jarak kelahiran yang lebih pendek dan lama menyusui yang lebih singkat $(2,6,7)$.

Besar sampel sangat menentukan akurasi estimasi angka lama menyusui untuk setiap provinsi. Dalam penelitian ini, meskipun hanya mengolah data dari anakanak yang telah disapih (data censored dikeluarkan dari analisis), sampel secara nasional masih sangat memadai (13.121 anak). Sementara itu, berdasarkan data laporan resmi SDKI tahun 2007, sampel secara keseluruhan sebesar 9.960 anak. Walaupun demikian, 9 provinsi memiliki besar sampel kurang dari 100 anak (8). Dari perbedaan sampel tersebut, penelitian ini dapat dikatakan memiliki estimasi lama menyusui per provinsi yang lebih baik. Sebagai contohnya adalah sangat diragukan apabila median menyusui pada 2 provinsi hanya sekitar 4 bulan. Meskipun demikian, tidak dapat dipungkiri bahwa bias yang terjadi disebabkan harus mengingat kembali peristiwa yang telah lalu (recalled bias) lebih tinggi pada analisis ini dibanding laporan resmi SDKI tahun 2007 (8).

Kecenderungan lama menyusui yang makin singkat belum pernah dilaporkan penelitian sebelumnya dengan skala nasional, demikian juga dugaan bahwa prevalensi ASI eksklusif yang menurun tidak didukung oleh data nasional, apalagi dari data survei longitudinal. Penelitian ini berhasil membandingkan dua panel survei nasional yang dilakukan tahun 2002-2003 dan tahun 2007. Tren penurunan lama menyusui dari data SDKI tahun 2007 dibandingkan dengan SDKI tahun 2003 menunjukkan bahwa lama menyusui dari waktu ke waktu cenderung menurun. Makin singkat lama menyusui akan diikuti dengan makin menurunnya prevalensi ASI eksklusif. Hal ini perlu mendapat perhatian serius dari pemegang kebijakan di tingkat nasional.

Perilaku modern untuk melahirkan di rumah sakit dan melakukan perawatan pascamelahirkan (postnatal care) menjadi faktor pembeda yang penting pada lamanya menyusui seorang ibu, demikian juga pertolongan oleh tenaga kesehatan yang dianggap paling terampil (doker umum dan spesialis) memiliki kaitan dengan lama menyusui ibu. Namun demikian, hubungan tersebut tidak seperti yang diharapkan. Perawatan pascamelahirkan oleh dokter umum atau dokter spesialis serta tempat melahirkan di fasilitas pelayanan kesehatan, khususnya rumah sakit tidak berhubungan secara positif dengan perilaku ibu untuk menyusui bayinya, tetapi justru berpengaruh negatif. Hal ini sejalan dengan penelitian yang dilakukan di Kupang, Nusa Tenggara Timur pada tahun 2004-2005 menemukan bahwa salah satu alasan ASI tidak diberikan secara eksklusif adalah perintah dari petugas kesehatan (17). Penemuan ini mendukung hipotesis tentang pengaruh negatif modernisasi terhadap pola menyusui. Tampaknya mempertahankan tradisi dalam praktik menyusui tidak dianggap menjadi salah satu perilaku modern, tetapi masih dianggap menjadi perilaku budaya yang tradisional. Sementara itu, modernisasi kesehatan dianggap harus disertai perubahan dengan simbol-simbol modern, seperti pemberian makanan dan minuman formula kepada anak. Kegagalan pendidikan pengetahuan dan perilaku menyusui ini mengundang tantangan baru mengenai cara meletakkan isu menyusui bayi sebagai isu kesehatan yang penting dalam upaya-upaya kesehatan ibu dan anak di Indonesia dan cara mempertahankan budaya kesehatan yang alamiah (menyusui) dari dampak modernisasi.

Pendidikan wanita telah terbukti berkaitan erat dengan proses reproduksi dan penerimaan budaya modern dalam keluarga. Banyak penelitian menyimpulkan bahwa pendidikan ibu menentukan partisipasinya dalam program $\mathrm{KB}(1,2,7$, $12,15,18)$. Bahkan terbukti keputusan bersama (joint decision) terjadi dalam penggunaan teknologi kesehatan modern untuk ibu dan anak (penggunaan kontrasepsi dan vaksinasi anak) (4). Dalam penelitian ini, wanita tidak sekolah dan berpendidikan rendah (hanya sampai SMP dan SMA) umumnya terpengaruh pada perilaku budaya tradisional. Pendidikan rendah justru berhubungan dengan perilaku yang baik dalam hal memberikan ASI, sedangkan wanita yang telah mengalami pendidikan tingkat universitas memiliki lama menyusui yang lebih pendek. Penemuan serupa terjadi di Filipina yang menyimpulkan bahwa faktor pendidikan merupakan determinan penting yang menentukan lamanya menyusui (12). Dengan demikian, pendidikan juga lebih 
berpengaruh sebagai perilaku modernisasi dan menyusui masih dianggap bagian dari perilaku budaya tradisional.

Kemiskinan menjadi penyebab sekaligus akibat dari proses untuk mengikuti modernisasi dalam kehidupan keluarga. Wanita dengan penghasilan rendah akan sulit memenuhi kebutuhan hidup modern. Pada penelitian ini, keluarga yang tergolong miskin cenderung tetap memelihara perilaku budaya tradisional, termasuk dalam menyusui bayi. Tidak mengherankan bahwa keluarga terkaya memiliki lama menyusui yang lebih singkat dibanding keluarga yang tergolong miskin. Penemuan ini sejalan dengan penemuan dari penelitian-penelitian sebelumnya di Filipina (12) dan di Kota Pekanbaru Indonesia (19). Keluarga miskin juga cenderung bertempat tinggal di daerah pedesaan yang memiliki fasilitas atau sarana modern lebih rendah dibanding daerah perkotaan. Wanita yang bertempat tinggal di desa memiliki kesempatan akses terhadap kehidupan modern yang lebih rendah dibanding dengan wanita yang tinggal di daerah perkotaan. Tidak dapat dipungkiri bahwa salah satu pemicu modernisasi adalah informasi dan teknologi yang tersedia di masyarakat. Sehubungan dengan hal tersebut, wanita dari perdesaan dapat dianggap lebih tertinggal dalam modernisasi dibandingkan dengan wanita dari daerah perkotaan.

Penelitian ini menggunakan survei nasional yang berskala luas yang pelaksanaannya diupayakan memiliki hasil berstandar internasional dan dapat dibandingkan dengan negara-negara lain. Meskipun demikian, penelitian survei memiliki kelemahan pokok yang tidak dapat dihindari. Salah satu kelemahan dalam survei yang menanyakan kejadiankejadian di masa lalu ialah adanya bias karena mengandalkan ingatan responden (recalled bias). Oleh karena itu, penelitian ini tidak dapat menghindari kelemahan tersebut karena lama menyusui didasarkan pada ingatan ibu.

Namun berbeda dengan informasi tentang lamanya menyusui yang tergolong censored, data ini lebih dapat dipertanggungjawabkan. Hal ini disebabkan karena data censored tersebut didasarkan pada kondisi pada saat survei (ibu sedang menyusui atau tidak) dan dihitung dari waktu anak dilahirkan. Kelemahan pengumpulan data lama menyusui tersebut dapat diperkirakan dari pola pelaporan lama menyusui yang mengumpul pada umur-umur tertentu (age heaping). Mengumpulnya hasil pengamatan lama menyusui pada umur kisaran tertentu (12, 18, 24, dan 36 bulan) tidak dapat disingkirkan dari kemungkinan terjadinya bias sehubungan dengan harus mengingat kembali peristiwa yang telah lalu (recalled bias). Tidak dapat dipastikan pula bahwa terdapat kebiasaan di masyarakat untuk menyapih anak pada umur-umur tertentu. Untuk itu, perlu dilakukan penelitian lebih lanjut terhadap pola age heaping tersebut, baik menggunakan data SDKI sebelumnya maupun menggunakan penelitianpenelitian yang bersifat kuantitatif dan kualitatif. Meskipun demikian, mempertimbangkan besar sampel data SDKI tahun 2007 yang cukup memadai, pola menyusui pada segmen umur-umur tertentu tersebut dapat dianalisis per segmen, sehingga dapat membantu pengambilan keputusan dalam program peningkatan penggunaan ASI.

\section{KESIMPULAN DAN SARAN}

Penelitian ini berhasil mengungkap pola menyusui yang bervariasi antarprovinsi di Indonesia. Variasi tersebut dapat dihubungkan dengan berbagai perilaku ibu, keluarga, dan masyarakat dalam mengikuti proses modernisasi. Dari penelitian ini dapat disimpulkan bahwa selama 5 tahun dari tahun 2002 sampai 2007 telah terjadi penurunan median lama menyusui sekitar 2 bulan. Proses modernisasi tidak dapat dipisahkan dari pemahaman dan praktik-praktik kehidupan sehari-hari yang memiliki nilai-nilai kultural bagi masing-masing keluarga. Sementara itu, dalam penelitian ini ditemukan praktik menyusui tidak selalu sejalan dengan keinginan modernisasi untuk meningkatkan derajat kesehatan dan kesejahteraan generasi yang akan datang. Misalnya, praktik modern tentang pemeliharaan kesehatan tidak selalu sejalan dengan pola menyusui seorang ibu yang makin baik. Sebaliknya, perilaku tradisional memiliki peran untuk tetap mempertahankan cara-cara menyusui yang lebih natural yang terbukti lebih sehat. Tarik-menarik kedua arah akan tetap terjadi. Modernisasi cenderung mengikis praktikpraktik sehat untuk menyusui, sedangkan mempertahankan perilaku menyusui secara alamiah sulit dipertahankan karena adanya stigma dalam mempertahankan tradisi dalam era modernisasi, meskipun tradisi tersebut memiliki arti positif.

Berdasarkan kesimpulan di atas, perlu dilakukan rekayasa sosial (social enginering) agar modernisasi tidak harus bertentangan dengan perilaku budaya tradisional yang memiliki dampak positif dalam perbaikan gizi dan kesehatan. Secara khusus, perlu dilakukan sosialisasi bahwa menyusui adalah perilaku budaya tradisional tetapi memiliki keuntungan yang didukung oleh pengetahuan modern. Oleh karena itu, tantangan yang saat ini dihadapi ialah agar cara menyusui dapat menjadi salah satu bagian dari konsep kehidupan modern. Untuk itu, harus dilakukan upaya-upaya promosi dan advokasi secara luas tentang konsep baru tersebut. Sosialisasi ini perlu dilakukan secara luas, akan tetapi harus dimulai dari tenaga kesehatan, gizi (profesi kesehatan), dan sektor pendidikan secara luas. Penelitian lanjutan yang dapat menjawab tantangan praktis cara mengubah pandangan dari menyusui sebagai perilaku budaya tradisional menjadi menyusui sebagai budaya modern dalam meningkatkan derajat kesehatan dan gizi anak di Indonesia perlu dilakukan.

\section{Ucapan terima kasih}

Penulis mengucapkan banyak terima kasih kepada semua tim peneliti SDKI 2007 dan staf kantor Pusat Kesehatan Reproduksi, Fakultas Kedokteran UGM. Penulis 


\section{RUJUKAN}

1. Black RE, Allen LH, Bhutta ZA, Caulfield LE, de Onis M, Ezzati $M$, et al. Maternal and child undernutrition: global and regional exposures and health consequences. Lancet 2008; 371(9608): 243-60.

2. Simondon KB. Early breast-feeding cessation and infant mortality in low-income countries. In: Goldberg G, Prentice A, Prentice A, Filteau S, Simondon K, editors. Springer Science +Business Media BV. Workshop Summary Breast-feeding: early influences on later health; 2009; New York, USA; 2009. p. 319-30.

3. World Bank. World Development Report 1993: Investing in Health. Washington DC: World Bank; 1993.

4. Wilopo SA, Mosley WH. Child Survival Intervention Programmes and The Practice of Contraception in West Timor Island, Indonesia. In: Department for Economic and Social Information and Policy Analysis Population Division, editor. Child Survival, Health and Family Planning Programmes and Fertility. New York: United Nations; 1996. p. 42-69.

5. Hanson LA, Silfverdal S-A, Hahn-Zoric M, Håversen L, Baltzer IM, Moisei M, et al. Immune Function In: Goldberg G, Prentice A, Prentice A, Filteau S, Simondon K, editors. Springer Science +Business Media BV. Workshop Summary Breast-feeding: early influences on later health; 2009; New York, USA; 2009. p. 97-111.

6. Ronsmans C. Maternal Mortality in Developing Countries In: Semba RD, Bloem MW, editors. Nutrition and health in developing countries. Totowa, New Jersey: Humana Press; 2001. p. 31-56.

7. Conde-Agudelo A, Rosas-Bermúdez A, Kafury-Goeta AC. Effects of birth spacing on maternal health: a systematic review. Am J Obstet Gynecol 2007; 196(4): 297 308.

8. Badan Pusat Statistik (BPS), International M. Survei Demografi dan Kesehatan Indonesia 2007. Calverton, Maryland, USA: BPS dan Macro International; 2007.

9. Badan Pusat Statistik (BPS), ORC Macro. Survei Demografi dan Kesehatan Indonesia 2002-2003. Calverton, Maryland, USA: ORC Macro International; 2003.
10. Ghofur A. Hubungan jarak kelahiran anak sebelumnya dan menyusui dengan mortalitas bayi di Indonesia (studi analisis hasil SDKI 2002-2003) [master tesis]. Yogyakarta: Universitas Gadjah Mada; 2004.

11. Coates MM, Riordan J. Tides in Breastfeeding Practice. In: Riordan J, editor. Breastfeeding and Human Lactation 3rd ed. Sudbury, MA: Jones and Bartlett Publishers Inc; 2005. p. 3-25.

12. Abada TSJ, Trovato F, Lalu N. Determinants of breastfeeding in the Philippines: A Survival Analysis. Soc Sci Med 2001; 52: 71-81.

13. Awaluddin. Hubungan struktur keluarga, pekerjaan dan pendidikan ibu dengan pemberian air susu ibu dan makanan pendamping ASI pada bayi usia kurang enam bulan di Indonesia (analisis data SDKI 2002-2003) [master tesis]. Yogyakarta: Universitas Gadjah Mada; 2006.

14. Asi M. Hubungan dukungan tempat bekerja dengan pemberian asi eksklusif di Kota Kendari Propinsi Sulawesi Tenggara [master tesis]. Yogyakarta: Universitas Gadjah Mada; 2006.

15. O'Donnell O, van Doorslaer E, Wagstaff A, Lindelow M. Analyzing health equity using household survey data. A guide to techniques and their implementation. Washington DC: The International Bank for Reconstruction and Development/ The World Bank; 2008.

16. StataCorp. Survival Analysis and Epidemiological Tables: Stata Statistical Sofware Release 9. College Station, TX, USA: StataCorp LP; 2005.

17. Soi $B$, Julia $M$, Budiningsari RD. Pengaruh status gizi ibu menyusui terhadap eksklusivitas pemberian ASI dan pertumbuhan bayi di RSUD Prof Dr WZ Johannes Kupang. Jurnal Gizi Klinik Indonesia 2006; 2(3): 101-7.

18. Bhutta ZA, Ahmed T, Black RE, Cousens S, Dewey K, Giugliani E, et al. What works Interventions for maternal and child undernutrition and survival. Lancet 2006; 371(9610): 417-40.

19. Zulfayeni, Julia M, Helmiyati S. Pengaruh dukungan pelayanan kesehatan terhadap pemberian ASI eksklusif pada bayi sampai usia 4 bulan di Kota Pekanbaru. Jurnal Gizi Klinik Indonesia 2005; 2(2): 53-9. 